\title{
Using Extrusion to Prepare Snacks Food High Nutrition Value Fortified with Soybean and Spinach for Children
}

\author{
Fizah M.M. Al-Subhi ${ }^{1}$
}

\begin{abstract}
This study was conducted to prepare snacks of defatted soybean, corn grits and spinach powder food blends. In raw materials and their blends, chemical composition, mineral content, total phenolics, and flavonoids were determined. In addition, blends were extruded, and food was prepared for snacks. Chemical composition, mineral content, total phenolics, flavonoids, physical characteristics and sensory evaluation were analyzed in blends and contrasted with the control made from corn grits. The results showed that defatted soybean was the highest in total protein $(51.60 \%)$, followed by defatted corn and spinach at 9.50 $\%$ and $6.30 \%$ respectively, and increased defatted soybean protein blends. Whereas spinach powder was the highest in total lipid, ash and crude fiber $(9.0,10.83$ and $17.67 \%$ respectively), followed by defatted soybean which was $6.93,5.22$ and $10.71 \%$ respectively; and their ash, total lipid and crude fiber blends were improved by increasing spinach powder. In addition, spinach powder and defatted soybean had contained the highest quantities of total dietary fiber 27.13 and 25.39 $\%$, soluble 9.45 and $8.73 \%$, and insoluble dietary fiber 17.86 and $16.66 \%$, respectively, with minor differences in total fiber fractions in their blends. Total phenolics and flavonoids as a pigment and antioxidant have been found in high quantities in spinach, defatted soybean and corn grains. The mineral contents in blends were increased by increasing minerals in raw materials during different additions. Ash, crude fiber and total dietary fiber were not affected by extrusion but increased after this process. The soluble dietary fiber was not affected by extrusion and increased after extrusion in the blends, and also decreased in the insoluble dietary fiber in all blends. Color control values and extruded blends showed that after addition of concentration of spinach powder, lightness ( $L$ value) and yellowness (b value) were decreased. Sensory evaluation, panelists gave lower overall acceptability scores for the extruded blend no. 3and 4. Even so, it hasn't significantly changed between the extruded blends no. 1 and 2 and the control snacks food. It can be concluded that the extrusion blends no.3 and 4 had the lowest in overall acceptability scores which may be due to the increasing concentration of spinach powder, from the obvious results. Extrusion blends no. 1 and 2 made from 40 and $30 \%$ defatted soybean flour were most liked by the taste panelists.
\end{abstract}

Key words: snacks food, defatted soybean, corn grits and spinach powder, nutrition value.

\section{INTRODUCTION}

Most snack foods produced today consist of starch from cereals, tubers or roots. Common snacks in various countries are therefore already enriched with animal or vegetable protein (Suknark, 1998). However, vegetable proteins are less costly and can be produced anywhere on earth. Soybean is an excellent source of protein fortifying starch-based snacks (Liu, 1997).

Snacks such as crackers, cookies, popcorn, potato chips, doughnuts and chocolate, they can be either salty or sweet and tend to be high in calories and fat (Ranhotra and Vetter, 1991) but low in protein, vitamins and other nutrients. Likewise crackers, cookies, popcorn, potato chips, doughnuts and chocolate, they can be either salty or sweet. In the United States, snack foods are very popular. The rate of snack food sales has been growing steadily in the last 10 years (Anonymous, 2001 ) with increases between $6.2 \%$ and $8.5 \%$. In the last 4 years on record, Peanuts have suffered particularly from a negative trend among the snack foods, influenced by public belief about healthy foods. Snack is a fast food that offers short-term hunger-satisfying calories and is often consumed in a hurry (Ocheme et al., 2011). Snacks also contain large quantities of sweeteners, preservatives and flavoring components that give the user a tasteful appeal (Ocheme et al., 2011). Snacks are eaten between meals in developed countries to check hunger, provide energy and delicious appeal; while snacks are eaten as the main meal in developing countries due to their ready availability and affordability. The small nature of snacks makes them handy, easy to be managed and carried about. In most developing countries, the method of snack production is largely a home art making the product considerably different in terms of nutritional quality, microbiological protection and sensory attributes from one group to another. The extrusion technology was used to manufacture a wide variety of raw materials from cereal flour, starch granules, tubers, legumes, etc. into semicooked or fully cooked appropriate food items such as cereals for breakfast, snacks, flakes, fast cooking pasta

\footnotetext{
DOI: 10.21608/ASEJAIQJSAE.2020.94865

General Nutrition, Family Education Department, Collage of Education, Umm Al-Qura University, Saudi Arabia Fmsubhi@uqu.edu.sa ----- Dr.faiza428@gmail.com

Received May 05, 2020, Accepted, , June 10, 2020.
} 
items, vegetable protein textures and gruel for breakfast (Iwe, 2001; Nwabueze et al., 2008 and Leszek, 2011). Lomnitski et al.,(2003) described the spinach's chemical composition, its beneficial effects, its relative safety information and its recommended human dietary inclusion. A powerful, water-soluble, natural antioxidant mixture (NAO) was isolated from spinach leaves, which specifically inhibits the lipoxygenase enzyme. NAO's antioxidant activity was contrasted with that of other recognized antioxidants and found to be in vitro and in vivo superior to that of green tea, $\mathrm{N}$ - acetyl cysteine (NAC), butylatedhydroxyltoluene (BHT), and vitamin E. Natural antioxidant mixture (NAO) has been tested for protection and is well tolerated in a variety of animals, including mouse, rat, and rabbit. NAO has been found to be non-mutagenic and has shown positive anti-carcinogenic effects in a few experimental models, such as skin and prostate cancer; no target organ toxicity or side effects have been observed. The current review provides epidemiological and preclinical evidence which support the effectiveness of spinach extracts and the safety of their consumption. Dietary activity involving human consumption of spinach has shown beneficial effects on the ophthalmic system. Spinach and collard greens consumption has been linked with a lower risk of age-related macular degeneration and cataracts according to Brown et al. (1999) and Moeller et al. (2000). Although the pathophysiology is complex and encompasses both environmental and genetic components, research suggests that dietary factors, including antioxidants, may contribute to a reduction in the risk of these degenerative eye diseases. Due to its high protein, vitamin and mineral compositions, soya has distinct nutritional values which offer health benefits (Obatolu et al. 2006). Health and medicinal benefits associated with soy protein include lower cholesterol levels in the blood (Anderson et al. 1995), cardiovascular disease prevention, and decreased risk of some cancers (prostate and breast) in humans (Peterson and Barnes 1991, 1993). The extrusion cooking of soy-corn blends has been documented in various studies (Seker, 2005). De Mesa et al. (2009) examined the manufacturing conditions and interactions between standard corn starch (NCS) and soy protein concentrate (SPC). The addition of 5-20\% SPC resulted in lower specific mechanical energy (SME) and NCS expansion, and higher extrudate mechanical strength. HACS expansion properties are also known to have been different from those of NCS Chimnaswamy and Hanna (1988).

Flavonoids and other phenolic constituents act as antioxidants by the free-radical scavenging properties of their hydroxyl groups. Extensive conjugation across the flavonoid structure and numerous hydroxyl groups enhance their antioxidative properties, allowing them to act as reducing agents, hydrogen- or electron-donating agents, or singlet-oxygen scavengers (Vinson et al., 2002).

The objective of this study was to create a new snack focused on defatted soybean, corn grits and spinach before and after extrusion; chemical analyzes were determined in the raw materials and their blends. After extrusion, color, physical properties and sensory assessment of the blends were calculated.

\section{MATERIALS AND METHODS}

\section{Materials:}

Defatted soybean, spinach and corn grits were obtained from local market west zone in Saudi Arabia. Spinach was purchased from local market then washed and cut to $1-2 \mathrm{~mm}$ slices (sliced thinly). The slices were frozen immediately in a frozen at $6^{\circ} \mathrm{C}$ for $6 \mathrm{~h}$ and perfection frozen at $-25^{\circ} \mathrm{C}$ for $18 \mathrm{~h}$. After this treatment the slices were dried promptly in a convection oven air circulation at $50 \pm 2^{\circ} \mathrm{C}$ for $24 \mathrm{~h}$ as described by Park (1987).

\section{Methods:}

Four blends of raw materials were prepared using raw materials, corn grits, defatted soybean and spinach. The first blend consisted of $50 \mathrm{~g}$ corn grits, $40 \mathrm{~g}$ defatted soybean and $10 \mathrm{~g}$ spinach, the second blend consisted of $50 \mathrm{~g}$ corn grits, $30 \mathrm{~g}$ defatted soybean and $20 \mathrm{~g}$ spinach, the third blend consisted of $50 \mathrm{~g}$ corn grits, $20 \mathrm{~g}$ defatted soybean and $30 \mathrm{~g}$ spinach and the fourth blend consisted of $50 \mathrm{~g}$ corn grits, $10 \mathrm{~g}$ defatted soybean and $40 \mathrm{~g}$ spinach. The test sample was made from 100 per cent corn grits.

\section{Chemical analysis of raw materials and their blends}

The percentage of moisture, fat, ash, crude fiber and crude protein content in raw materials and their blends is calculated after and before extrusion using the Association of Official Analytical Chemists (AOAC, 2005) methods. Complete carbohydrate was measured using the differential method (McDonald et al., 1973). In addition, total dietary fiber was calculated according to the methods defined by Prosky (1988) in the raw materials and their blends after and before extrusion. Soluble and insoluble dietary fibers have also been established in raw materials and their blends after and before extrusion according to Lee and Prosky (1995). In the diluted solution of ash raw materials, the mineral content cupper $(\mathrm{Cu})$, potassium $(\mathrm{K})$, calcium $(\mathrm{Ca})$, magnesium $(\mathrm{Mg})$, iron $(\mathrm{Fe})$, sodium $(\mathrm{Na})$, phosphorus $(\mathrm{P})$ and manganese $(\mathrm{Mn})$ were calculated using the atomic absorption spectrophotometer (3300 PerkinElme), as defined in the AOAC method (2005). 


\section{Determination of total phenolic compounds}

The Folin-Ciocalteu process used to evaluate total phenolic compounds (Ragazzi and Veronese, 1973). The phenolic compound contents were calibrated using the linear equation base on the calibration curve. The content of phenolic compounds was expressed in the form of $\mathrm{mg}$ catechin equivalent / $\mathrm{g}$ dry weight. The indicated dry weight was dry weight of water spinach.

\section{Determination of total flavonoid content}

The AlCl3 method (Lamaison and Carnet, 1990) was used to assess the total flavonoid content in the sample extracts. Inhaled in flavonoids were expressed as $\mathrm{mg}$ catechin equivalent/g dry weight. The dry weight indicated was water spinach dry weight.

\section{Sample preparation for extrusion}

Through water addition by material balance, the flour blend was brought separately to $21 \% \mathrm{MC}$ (Nwabueze and Iwe, 2010). Brabender laboratory extruder (Duisburg DCE 330, New Jersey, USA) fitted with $2 \mathrm{~mm}$ die nozzle. The extruder had 20:1 ratio of grooved barrel length to diameter (L / D) worked at a steady $140 \mathrm{rpm}$ and $1400^{\circ} \mathrm{C}$ barrel temperature screw speed (ss). It employed a screw compression ratio of $4: 1$ (Nwabueze, 2007). Die nozzle's diameter and length was $2 \mathrm{~mm}$ and $40 \mathrm{~mm}$, respectively. Thermostatadjusted temperature settings such as that temperature level of $120,150,170$, and $1500^{\circ} \mathrm{C}$ were used for feeding, compression, metering and dietary region. The extruder was allowed to stabilize with corn flour before the test runs began at a speed of 40rpm. The feed was added gradually but continuously to the feed hopper fitted with a $300 \mathrm{~g} /$ min auxiliary anger screw and was received at the end as pellet strands. The emerging extrudates as pellets at the die nozzle were collected and spread under fan on the laboratory table at room temperature $\left(28 \pm 2.0^{\circ} \mathrm{C}\right)$ for $3 \mathrm{~h}$. The extrudates were later dried in an air convection oven (Gallenkamp, England) at $600{ }^{\circ} \mathrm{C}$ for $10 \mathrm{~h}$. The resulting dried extrudates were packaged inside coded high density polyethene bag. The resulting extrudates flour was packaged inside coded high density polyethene bag and stored under room temperature $\left(28 \pm 2.0^{\circ} \mathrm{C}\right)$ until needed for analysis.

\section{Color and physical properties:}

Color of dried couscous samples were evaluated by measuring the yellowness (b value) and brightness ( $\mathrm{L}$ value) using a Hunter Lab. Colorimeter model D 25 according to Francis (1998). Snacks water absorption index (WAI) and snacks solubility index (WSI) were determined according to the method of Anderson et al., (1969).

\section{Sensory evaluation of snack blends:}

The snacks blends were organoleptically evaluated for their taste, color, mouth-fell and flavor by twenty experienced panelists from the staffs of Nutrition and Food Science Department, Umm Al-Qura University, Saudi Arabia.

\section{Statistical analysis:}

The data obtained were analyzed by using SPSS statistical software (version 13 SPSS Inc., Chicago. USA). The results were expressed as mean $\pm \mathrm{SD}$, and tested for significance using one-way analysis of variance "ANOVA" according to Armitage and Berry (1987).

\section{RESULTS AND DISCUSSION}

\section{Chemical composition of raw materials and their blends:}

Chemical constituents, total phenolics, total flavonoid compounds and dietary fiber fractions were determined in raw materials (corn grits, defatted soybean and spinach powder) and their blends and the results are recorded in Table (1). The results showed that the defatted soybean have been the highest in total protein $(51.60 \%)$ followed by corn grits and spinach were 9.50 and $6.30 \%$, respectively and the blends were increased in protein by increasing defatted soybean. Whereas, spinach powder was the highest in total lipid, ash and crude fiber (9.0, 10.83 and $17.67 \%$, respectively) followed by defatted soybean was 6.93 , 5.22 and $10.71 \%$, respectively and their blends were increased in ash, total lipid and crude fiber by increasing spinach powder.

Total dietary fiber, soluble and insoluble dietary fibers were determined in the raw materials and their blends and the results are reported in the same Table. From the results, it could be noticed that the spinach powder and the defatted soybean had contained the highest amounts in total dietary fiber 27.13 and $25.39 \%$, soluble 9.45 and $8.73 \%$ and insoluble dietary fiber 17.86 and $16.66 \%$, respectively, and their blends were slightly in variations for total fiber fractions.

Many researchers have shown the relationship between legume consumption and health benefits, such as, protection from cardiovascular disease, breast cancer, colon cancer, other cancers and diabetes (Kushi et al. 1999 and Mathers, 2002). Total phenolics and flavonoids as a pigment and antioxidant were found in spinach, defatted soy bean and corn grits with high amounts. 
Table 1. Chemical composition of raw materials and their blends on dry weight basis $(\mathrm{g} / \mathbf{1 0 0 g})$

\begin{tabular}{lccccccc}
\hline Chemical analysis & $\begin{array}{c}\text { Corn } \\
\text { grits }\end{array}$ & $\begin{array}{c}\text { Defatted } \\
\text { soybean }\end{array}$ & $\begin{array}{c}\text { Spinach } \\
\text { powder }\end{array}$ & Blend 1 & Blend 2 & Blend 3 & Blend 4 \\
\hline Protein & 9.50 & 51.60 & 6.30 & 24.1 & 20.64 & 15.51 & 10.28 \\
Ash & 0.65 & 6.93 & 10.83 & 4.25 & 4.65 & 5.05 & 5.45 \\
Lipid & 0.94 & 5.22 & 9.00 & 4.00 & 4.50 & 5.00 & 5.50 \\
Crude fiber & 0.71 & 10.71 & 17.67 & 6.60 & 7.30 & 8.00 & 8.70 \\
Total carbohydrate & 88.20 & 25.54 & 54.20 & 61.05 & 62.91 & 66.44 & 70.07 \\
Total phenolics mg/100g & 116.52 & 110.0 & 1274 & 336 & 452 & 530 & 624 \\
Total flavonoids mg/100g & 58.85 & 81.40 & 596.0 & 123 & 175 & 226 & 258 \\
Total dietary fiber & 2.27 & 25.39 & 27.31 & 14.2 & 14.4 & 14.6 & 14.8 \\
Soluble dietary fiber & 0.61 & 8.73 & 9.45 & 4.1 & 4.2 & 4.3 & 4.4 \\
Insoluble dietary fiber & 1.62 & 16.66 & 17.86 & 10.1 & 10.2 & 10.3 & 10.4 \\
\hline
\end{tabular}

Spinach with the highest amounted in total phenolics and flavonoids (1274 and $596 \mathrm{mg} / 100 \mathrm{~g}$ ) followed by corn grits $116.52 \mathrm{mg} / 100 \mathrm{~g}$ and defatted soybean $110.0 \mathrm{mg} / 100 \mathrm{~g}$ in total phenolics. Moreover, total flavonoids were $81.4 \mathrm{mg} / 100 \mathrm{~g}$ in defatted soybean and $58.85 \mathrm{mg} / 100 \mathrm{~g}$ in corn grits, and also their blends were the slightly increased gradually by increasing spinach powder.

In stabilizing lipid oxidation, polyphenolic compounds play an important role and are associated with antioxidant activity (Yen et al., 1993). The phenolic compounds could directly contribute to antioxidant action (Duh et al., 1999). Polyphenolic compounds are suspected to have inhibitory effects on mutagenesis and carcinogenesis in humans when up to $1.0 \mathrm{~g}$ is consumed daily from a fruit- and vegetable-rich diet (Tanaka et al., 1998).

\section{Minerals content of raw materials and their blends:}

Minerals content was determined in raw materials and their blends and the results are recorded in Table (2). The results showed that the spinach powder was found the highest amount in minerals content $\mathrm{Ca}, \mathrm{Mg}$, $\mathrm{Mn}, \mathrm{Fe}, \mathrm{Na}$ and $\mathrm{P}(416.7,301.64,214,210.30,135$ and $109.29 \mathrm{mg} / 100 \mathrm{~g}$, respectively). Defatted soybean had contained the highest amount in minerals content $\mathrm{P}, \mathrm{K}$, $\mathrm{Mg}$ and $\mathrm{Ca}$ (685, 360, 309 and $220 \mathrm{mg} / 100 \mathrm{~g}$, respectively. Corn grits illustrated that the highest amount in minerals content $\mathrm{P}, \mathrm{K}, \mathrm{Mg}$ and $\mathrm{Na}$ (376.46, $264.20,137.14$ and $110.95 \mathrm{mg} / 100 \mathrm{~g}$, respectively. Whereas, the minerals content in blends were increased by increasing minerals in raw materials during different addition.

In addition, considering potassium depresses while sodium increases blood pressure, the presence of high levels of hypertension could be a significant factor (Yoshimura et al., 1991). For the proper development and functioning of bone, teeth and muscles, calcium and phosphorous are linked to each other (Turan et al., 2003). The world health organization (WHO) estimates that iron deficiency affects approximately 3.7 billion people

Table 2. Minerals content of raw materials and their blends $\mathbf{m g} / \mathbf{1 0 0 g}$

\begin{tabular}{lccccccc}
\hline $\begin{array}{l}\text { Minerals } \\
\text { content }\end{array}$ & Corn grits & $\begin{array}{c}\text { Defatted } \\
\text { soybean }\end{array}$ & $\begin{array}{c}\text { Spinach } \\
\text { powder }\end{array}$ & Blend 1 & Blend 2 & Blend 3 & Blend 4 \\
\hline $\mathrm{K}$ & 264.20 & 360 & 5.46 & 290 & 255 & 217 & 175 \\
$\mathrm{Na}$ & 110.95 & 25.04 & 135.0 & 78 & 91 & 102 & 114 \\
$\mathrm{Ca}$ & 33.09 & 220.0 & 416.70 & 147 & 167 & 187 & 207 \\
$\mathrm{Mg}$ & 137.14 & 309.0 & 301.64 & 213 & 212 & 211 & 210 \\
$\mathrm{P}$ & 376.46 & 685.0 & 109.29 & 490 & 430 & 370 & 310 \\
$\mathrm{Cu}$ & 0.60 & 2.30 & 0.36 & 1.1 & 0.98 & 0.82 & 0.74 \\
$\mathrm{Fe}$ & 7.65 & 11.0 & 210.30 & 30 & 49 & 69 & 89 \\
$\mathrm{Mn}$ & 1.98 & 2.8 & 214.0 & 20 & 46 & 68 & 90 \\
\hline
\end{tabular}




\section{Chemical composition of blends extruded}

Chemical constituents, total phenolics, total flavonoid compounds and dietary fiber fractions were determined in extrusion blends made from different amounts of raw materials and the results are recorded in Table (3). From the results, it could be noticed that the blends after extrusion were decreased than the blends before extrusion. Moreover, blend no. 1 showed the highest in protein $(21.69 \%)$ followed by blends no. 2 and $3(18.52$ and $13.11 \%)$ and blend no. 4 was nearly or equal to control corn grits at 8.10 and $8.55 \%$, respectively. These increases in protein may be due to the increased amounts of defatted soybean that was added and defatted soybean was the highest protein at $51.60 \%$. The ash, crude fiber and total dietary fiber were not affected using extrusion but increasing after this process. These gradually increases in ash, crude fibers and total dietary fiber fractions from blend no. 1 to blend no. 4 may be caused by spinach which has the highest in ash, crude fibers and total dietary fiber at $10.83,17.67$ and $27.31 \%$, respectively; followed by defatted soybean at $6.93,10.71$ and $25.39 \%$, respectively. The soluble dietary fiber was not affected using extrusion and it was increased in the blends after extrusion and also the insoluble dietary fiber was decreased in all blends. This increase in soluble dietary fiber and decrease in insoluble dietary fiber may be also due to the breaking of some bond in the polysaccharides, also some Millard reaction products may be formed (Periago et al. 1996).

During extrusion cooking, the chemical constituents of the cooked material are subjected to high temperature, high shear and high pressure and these improve or damage the protein's nutritional quality through various mechanisms in the extruded material (Leszek, 2011).

Peptides of proteins undergo massive unfolding and/or aggregation during extrusion and this releases peptides of low molecular weight, thereby enhancing their digestibility.

Extrusion cooking generally disrupts the disulphide and linear connections of peptides at random, thereby increasing protease cleavage sites of the amino acids in themolecule.

This is very important in food materials dependent o $\mathrm{n}$ legumes. Yet making an extensive isopeptides cross linked networks with carbohydrates and lipids alter the active sites of protease interfering with their catalytic activities with a resultant decrease in their digestibility (Phillips, 1989).

The results in the same Table showed that the total phenolics and flavonoids in blends after extrusion have been affected and decreasing about $20 \%$ than the blends before extrusion.

Physical characteristics of extruded snacks food.

The physical characteristics such as color, water absorption index (WAI) and water soluble index (WSI) in control and their extruded blends are presented in Table (4). Color is a prime factor in judging snacks food products quality. The consumers select snacks food products for appearance, with the judgment based on the brightness of the color. The results in Table (4) showed the Hunter color values of control and extruded blends. From the obtained results, it could be noticed that lightness ( $\mathrm{L}$ value) and yellowness (b value) were decreased after addition of spinach powder concentration. Relatively, the amount of spinach powder addition (20\%) did not affect the yellowness and lightness that may be tinted.

Table 3. Chemical composition of blends extruded on dry weight basis (g/100g)

\begin{tabular}{lccccc}
\hline Chemical analysis & Control & Blend 1 & Blend 2 & Blend 3 & Blend 4 \\
\hline Protein & 8.55 & 21.69 & 18.52 & 13.11 & 8.10 \\
Ash & 0.95 & 4.82 & 5.26 & 5.53 & 5.95 \\
Lipid & 0.85 & 3.6 & 4.05 & 4.5 & 5.0 \\
Ctude fiber & 0.87 & 7.72 & 8.73 & 9.65 & 10.52 \\
T.C. & 88.83 & 62.17 & 63.44 & 67.21 & 70.43 \\
Total phenolics mg/100g & 93.22 & 268.8 & 361.6 & 424 & 499.2 \\
Total flavonoids mg/100g & 47.08 & 98.4 & 140 & 180.8 & 206.4 \\
TDF & 2.62 & 15.62 & 15.84 & 16.06 & 16.28 \\
SDF & 1.27 & 6.71 & 6.82 & 6.93 & 7.04 \\
IDF & 1.35 & 8.91 & 9.02 & 9.13 & 9.24 \\
\hline
\end{tabular}

TDF: Total Dietary Fiber SDF : Soluble Dietary Fiber IDF : Insoluble Dietary Fiber T.C: Total Carbohydrates. 
Table 4. Physical characteristics of extruded snacks food

\begin{tabular}{|c|c|c|c|c|}
\hline \multirow{2}{*}{ Blends } & \multicolumn{2}{|c|}{ Color } & \multirow{2}{*}{ WAI* } & \multirow{2}{*}{ WSI* } \\
\hline & $\mathbf{L}$ & B & & \\
\hline Control & 80.14 & 31.71 & 3.30 & 5.12 \\
\hline Blend 1 & 77.64 & 29.76 & 4.25 & 4.92 \\
\hline Blend 2 & 75.24 & 28.32 & 4.61 & 4.73 \\
\hline Blend 3 & 73.94 & 27.76 & 5.22 & 4.42 \\
\hline Blend 4 & 70.21 & 24.52 & 5.73 & 4.27 \\
\hline
\end{tabular}

WAI: Water Absorption Index, results expressed as weight of gel/gram of dry samples WSI: Water Solubility Index, result expressed as percent of dry solids in the supernatant. Hunter color values, L: lightness, B: yellowness.

These results were in agreement with Marty (1986) who reported that high barrel temperature and pressure of the extrusion cooker induce a cis-trans isomerization reaction of the carotene pigments with the formation of compounds that have the same spectral characteristics as the cis-b- carotene. Their finding is perhaps why the b value did not differ because the carotene pigment content of the extrusion-cooked couscous was not significantly different from the other three products.

Water absorption index (WAI) was used to assess this quality factor. Extrusion blends had significantly higher WAI than snacks food control. This may be attributed in part to the high proportion of gelatinized starch found in the extrusion blends. Debbouz (1992) found a high correlation between WAI and starch gelatinization. Water soluble index (WSI) expresses the percentage of dry matter recovered after the supernatant is evaporated from the water absorption determination. The results in the same Table showed that no significant difference in WSI was found between the extrusion and control snacks food. The growth of extruded WAI at the increase of the screw speed was due to an increase in starch gelatinization and an increase in SME input (Colonna et al., 1989 and Osman et al., 2000). Lower water absorption index (WAI) was increased by decreasing defatted soybean and was probably due to reduced starch content, which means less starch is available to be gelatinized during extrusion and subsequently absorb water (Colonna et al., 1989). Water solubility index (WSI) is reported to positively correlate with the degree of molecular degradation. The increase in WSI could be due to more soluble protein extruded (Tang and Ding, 1994).

\section{Sensory evaluation of extruded snacks food and their blends}

Color, mouth-feel, flavor and overall acceptability of the extruded blends and control snacks food were evaluated by a sensory panel and the results are reported in Table (5).The results showed that the sensory evaluation, panelists gave lower overall acceptability scores for the extruded blend no. 3and 4. Also, it did not significantly change between extruded blends no. 1 and 2 and control snacks food in mouth feel and flavor; whereas, the changed was found in color. This means that the color of the blends was affected adversely by the addition of spinach powder. From the obvious results, it could be concluded that the extruded blends snacks food showed an increase in protein, total dietary fiber and minerals than that of control snacks food. Moreover, physical characteristics, water absorption index, extruded blends are increased than in control. Also, the sensory evaluation showed that the blends no. 3 and 4 (the lowest in overall acceptability scores) may be due to the increasing concentration of spinach powder. Extruded blends no. 1 and 2 made from 40 and $30 \%$ defatted soybean flour were most liked by the taste panelists.

Table 5. Sensory evaluation of extruded snacks food and their blends

\begin{tabular}{lcccc}
\hline Blends & Color (30) & Mouth-feel (40) & Flavor (30) & Overall acceptability (100) \\
\hline Control & $29.21 \pm 1.25^{\mathrm{a}}$ & $38.45 \pm 2.01^{\mathrm{a}}$ & $28.57 \pm 1.67^{\mathrm{a}}$ & 96.23 \\
Blend 1 & $28.85 \pm 1.14^{\mathrm{a}}$ & $37.81 \pm 2.12^{\mathrm{a}}$ & $28.13 \pm 1.53^{\mathrm{a}}$ & 94.79 \\
Blend 2 & $27.31 \pm 1.52^{\mathrm{a}}$ & $36.57 \pm 1.98^{\mathrm{a}}$ & $27.97 \pm 1.81^{\mathrm{a}}$ & 91.85 \\
Blend 3 & $23.56 \pm 1.36^{\mathrm{b}}$ & $35.24 \pm 1.87^{\mathrm{b}}$ & $26.17 \pm 1.72^{\mathrm{b}}$ & 84.97 \\
Blend 4 & $20.12 \pm 1.24^{\mathrm{c}}$ & $30.56 \pm 1.54^{\mathrm{c}}$ & $22.34 \pm 1.61^{\mathrm{c}}$ & 73.02 \\
LSD at 5\% & 1.923 & 1.893 & 1.431 & \\
\hline
\end{tabular}

a,b,c Mean in the same column with different superscript differ significantly at $\mathrm{p} \leq 0.05$ 


\section{REFERENCE}

Anderson, R.N., H.F, Conway, V. H. Pfeifer and E. L. Griffin. 1969. Gelatinization of corn grits by roll and extrusion cooking. Cereal Sci. Today. 14: 4-8.

Anderson, J. W., B. M. Johnstone and M. E. Cook-Newell. 1995. Meta-analysis of the effects of soy protein intake on serum lipids. The New England J. of Medicine. 333 (5): 276-282.

Anonymous, S. 2001. State of the industry. Snack Foods and Wholesale Bakery. 90(10):1-38.

AOAC. 2005. Association of Official Analytical Chemists. Official Methods of Analysis $17^{\text {th }}$ ed. AOAC. Arlington, Virginia. 2220 USA.

Arai, S. 2002. Global view on functional foods: Asian perspectives. Brit. J. Nutr. 88: S139-S143.

Armitage, P and G. Berry. 1987. Statistical Method in Medical Research. Blackwell, Oxford. UK.. 93- 213.

Brown, L., E. B. Rimm, J. M. Seddon, E. L. Giovannucci, and L. Chasan-Taber. 1999. A prospective study of carotenoid intake and risk of cataract extraction in US men. Am J Clin Nutr. 70:517-524.

Chimnaswamy, R. and M. A. Hanna. 1988. Relationship between amylose content and extrusion-expansion properties of corn starches. Cereal Chemistry. 65 (2): $138-143$.

Colonna, P.J., J. Tayeb and C.Mercier. 1989. Extrusion cooking of starch and starchy products. In: Mercier, C., Linko, P., Harper, J.M (Eds.), Extrusion Cooking. American Association of Cereal Chemists, Inc., St Paul, MN. 247-319.

Debbouz, A. 1992. Influence of raw material and processing on couscous quality. Ph. D. Thesis, North Dakota State Univ., Fargo, ND.

De Mesa, N.J.E., A. Sajid, N. Singh, Y.C. Shi, H.Dogan and Y.Sang. 2009. Soy proteinfortified expanded extrudates: baseline study using normal corn starch. J. of Food Engineering. 90 (2), 262-270.

Duh, P.D., Y.Y. Tu and G.C. Yen. 1999. Antioxidant activity of water extract of Harng Jyur (Chyrsanthemum morifoliumRamat). Lebensmittel- Wissenschaft und Technologie. 32: 269-277.

Francis, F. J., 1998. Clolur analysis in S. S. Nielson (ed), Food Analysis Maryland: Chapman and Hall.

Iwe, M. O., 2001. Organoleptic assessment of extruded blends of soy and sweet potato flour by response surface analysis. Plants Foods for Human Nutrition. 60:1-14.

Kushi, L.H., K. A. Meyer and D. R. J. Jacobs. 1999. Cereals, legumes, and chronic disease risk reduction: evidence from epidemiologic studies. Am. J. Clin. Nutr. 70: 451S-458S.

Lamaison, J.L.C. and A.Carnet. 1990. Teneurs en principaux flavonoids des fleurs de Crataegeus monogyna Jacq et de Crataegeus laevigata (Poiret D. C) en fonction de la vegetation. Pharm. Acta. Helv. 65: 315- 320 .
Lee, S. C. and L. Prosky. 1995. International survey on dietary fiber definition, analysis and materials. JAOAC. 78: $22-36$

Leszek, M. 2011. Extrusion-Cooking Techniques Applications, Theory and Sustainability. WILEY-VCH Verlag and Co. KGaA, Weinheim, Germany.

Liu, K. 1997. Soybeans: Chemistry, Technology and Utilization. Book from International Thompson Publishing. Florence, KY. 25 -113.

Lomnitski, L., M. Bergman, A. Nyska, V. Ben-Shaul and S. Grossman. 2003. Composition, efficacy, and safety of spinach extracts. Nutrition and Cancer. 46(2): 222231.

Marty, C., 1986. Isolement et identification des composes de degradation thermique du B-carotene all-tans. Stabilite comparee de quelques pigments carotenoids en caisson- extrusion. These de dotorat Universite Paris Vll. Paris

Mathers, J. C. 2002. Pulses and carcinogenesis: potential for the prevention of colon, breast and other cancers.Br. J. Nutr. 88: 273-279.

McDonald, P., R.A. Edwards and J.F.D. Green-halgh. 1973. Animal Nutrition. T and A Constable Ltd., Edinburgh. 2-5.

Moeller, S. M., P. F. Jacques and J. B Blumberg. 2000. The potential role of dietary xanthophylls in cataract and age-related macular degeneration. J Am Coll Nutr. 19:522-527.

Nwabueze, T. U. 2007. Effects of process variables on trypsin inhibitor activity (TIA), phytic acid and tannin content of extruded African breadfruit-soy-corn mixtures: A response surface analysis. J. of Food Science and Technology. 40(1):21-29.

Nwabueze, T. U. and M. O. Iwe. 2010. Residence time distribution (RTD) in a single screw extrusion of African breadfruit mixtures. Food Bioprocess Technology. 3:135-145.

Nwabueze, T. U., M. O. Iwe and E. N.T. Akobundu. 2008. Physical characteristics and acceptability of extruded African breadfruit-based snacks. J. of Food Quality. 31(2): 142-155.

Obatolu, V.A., O.O. Olusola and A.A. Adebowale. 2006. Qualities of extruded puffed snacks from maize/soybean mixture. Journal of Food Process Engineering. 29:149-161.

Ocheme, O. B., C.C. Ariahu and M. O. Igyor. 2011. Assessment of traditionally produced Dakuwa (A cereal/legume based Nigerian snack) in Niger state, Nigeria. Nigerian Food J. 29(1): 63-69.

Osman, M.G., D. Sahai and D.S. Jackson. 2000. Oil absorption characteristics of a multigrain extrudate during frying: effect of extrusion temperature and screw speed. Cereal Chemistry. 77 (2):101-104.

Park, Y. W. 1987. Effect of Freezing, Thawing, Drying and Cooking on Carotene Retention in Carrots, Broccoli and Spinach. J. Food Sci. 52(4):1022-1025. 
Phillips, R.D. 1989. Effect of extrusion cooking on the nutritional quality of plant proteins, in Protein Quality and the Effect of Processing, ed. R. D. Phillips, J.W. Finley, Marcel Dekker, New York. 219-246.

Periago, M. J., H. N. Englyst and G. J.Hudson. 1996. The influence of thermal processing on the non-starch polysaccharides (NSP) content and in vitro digestibility of starch in pea lebensmwiss. Technol. 29:33- 40.

Peterson, T.G. and S. Barnes. 1991. Genistein inhibition of the growth of human breast cancer cells: independence from estrogen receptors and the multi-drug resistance gene. Biochemical and Biophysical Research Communications. 179 (1):661-667.

Peterson, T.G. and S. Barnes. 1993. Genistein and biochanin- an inhibit the growth of human prostate cancer cells but not epidermal growth-factor receptor tyrosine autophosphorylation. Prostate. 22 (4):335-345.

Prosky, L., N. G. Asp, T. F. Schweizer, J. W. Devries and I. Furda. 1988. Determination of insoluble and soluble and total dietary fiber in food product: Inter Laboratory Study .J. Assoc. of Anal. Chem. 71: 1017-1023.

Ragazzi, E. and G. Veronese. 1973. Quantitative analysis of phenolics compounds after thin-layer chromatographic separation. J. Chromatogr. 77: 369375.

Ranhotra. G. S. and J. L. Vetter. 1991. Foods considered for nutrient addition: Snacks and confectionaries. 208213.
Seker, M., 2005. Selected properties of native or modified maize starch/soy protein mixtures extruded at varying screw speed. J. of the Sci. of Food and Agriculture. 85:1161-1165.

Suknark, K. 1998. Development of extrusion processes for novel snack food production and the physicochemical and nutritional properties of resulting products. Dissertation, Department of Food Science and Technology. University of Georgia, Athens. GA. 99145.

Tanaka, M., C.W. Kuei and Y. Nagashima. 1998. Taguchi. Application of antioxidative maillrad reaction products from histidine and glucose to sardine products. Nippon Suisan Gakkaishil. 54: 1409-1414.

Tang, J. and X.L. Ding. 1994. Relationship between functional properties and macromolecular modifications of extruded corn starch. Cereal Chemistry. 71: 364369.

Turan, M., S. Kordali, H. Zengin, A. Dursun and Y. Sezen, 2003. Macro and micro minerals content of some wild edible leaves consumed in Eastern Anatolia. Acta Agric. Sccandinavica, Section B, Plant Soil Sci. 53: L129-137.

Yen, G.C., P. D. Duh and C. L. Tsai. 1993. Relationship between antioxidant activity and maturity of peanut hulls. J. Agric. Food Chem. 41: 67-70.

Yoshimura, M., H. Takahashi and T. Nakanishi. 1991. Role of sodium, potassium, calcium and magnesium on blood pressure regulation and antihypertensive dietary therapy. Jap. J. Nutr. 49: 53-62. 


\section{الملخص العربي}

استخدام جهاز البثق الحراري في تحضير أغذية خفيفة عالية القيمة الغذائية مدعمة بفول الصويا والسبانخ

\section{للأطفال}

$$
\text { فايزه مساعد محمد الصبحي }
$$

بزيادة مطحون السبانخ. مطحون السبانخ وفول الصويا منزوع الدهن كانت تحتوي على نسبة عالية من الألياف الغذائية

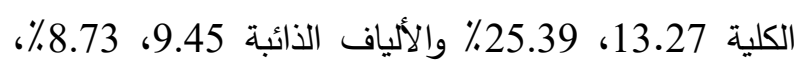

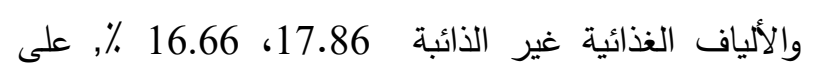

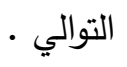

حدث انخفاض في التركيب الكيميائي للخلطات المعاملة بالبثق الحراري مقارنة بالخلطات قبل المعاملة فيما عدا الرماد

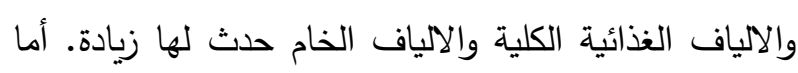
اللون في خلطات الأغذية الخفيفة حدث له انخفاض بزيادة إضافة السبانخ، وأما التقييم الحسي بالنسبة للخلطات فإن المحكمين أعطوا أقل قيمة للخلطات 3-4 ولكن الخلطات 1-2 لم يحدث بها تغير ملحوظ مقارنة بالعينة القياسية، لذلك يمكن أن نوصي بالخلطات من الأغذية الخفيفة التي تحتوي على فول صويا منزوع الدهن بنسب 30- 40٪ بـان ديث كانت مقبولة من حيث اللون والطعم بالنسبة للمحكمين.
في هذه الدراسة تم تحضير خلطات من الأغذية الخفيفة من فول الصويا منزوع الدسم ومجروش الذرة ومطحون السبانخ. تم تقدير التركيب الكيميائي ومحتوى المعادن والفينولات الكلية والفلافونيدات في المواد الخام وخلطاتهم. كما تم تقدير التركيب الكيميائي ومحتوى المعادن والفينولات الكلية والفلافونيدات والصفات الطبيعية والتتييم الحسي في خلطات الأغذية الخفيفة التي تم معاملاتها بجهاز البثق الحراري ومقارنتها بالعينة القياسية المحضرة من مجروش الذرة.

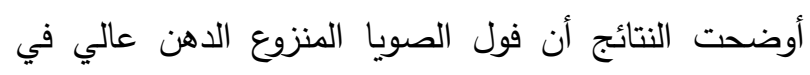
محتوى البروتين (51.60\%) ويليه مجروش الذرة ومطحون السبانخ 9.50، 6.30٪ على التوالي، كما أن الخلطات يحدث لها زيادة في نسبة البروتين بواسطة زيادة إضافة فول

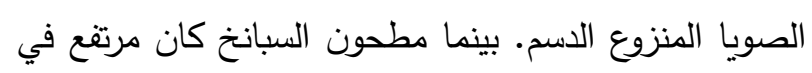
نسبة الليبدات والرماد والألياف الخام (9.0، 10.83، ليأم مطن 17.67 \%, على التوالي) تليها فول الصويا منزوع الدهن (6.93، 5.22، 10.71 \%، على التوالي)، كما أن الخلطات زادت 